\title{
PLANNED BEHAVIOR AND RELIGIOUS BELIEFS AS ANTECEDENTS TO ENTREPRENEURIAL INTENTION: A STUDY WITH UNIVERSITY STUDENTS
}

\author{
LUIS E. B. PAIVA ${ }^{1}$ \\ (iD) https://orcid.org/0000-0002-5036-6823 \\ EVANGELINA S. SOUSA ${ }^{1}$ \\ (iD) https://orcid.org/0000-0002-8455-1824 \\ TEREZA C. B. LIMA \\ (iD) https://orcid.org/0000-0002-6594-4921 \\ DIRCEU DA SILVA \\ (iD https://orcid.org/0000-0003-3267-511X
}

To cite this paper: Paiva, L. E. B., Sousa, E. S., Lima, T. C. B., \& Silva, D. (2020). Planned behavior and religious beliefs as antecedents to entrepreneurial intention: A study with university students. Revista de Administração Mackenzie, 21 (2), 1-27. doi:10.1590/1678-6971/eRAMG200022

Submission: Feb. 19, 2019. Acceptance: Sept. 26, 2019.

1 Universidade Federal do Ceará (UFC), Fortaleza, CE, Brazil.

2 Universidade Estadual de Campinas (Unicamp), Campinas, SP, Brazil.

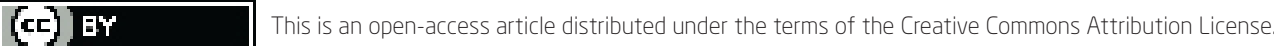

\footnotetext{
This paper may be copied, distributed, displayed, transmitted or adapted if provided, in a clear and explicit way, the name of the journal, the edition, the year and the pages on which the paper was originally published, but not suggesting that RAM endorses paper reuse. This licensing term should be made explicit in cases of reuse or distribution to third parties. It is not allowed the use for commercial purposes.

Este artigo pode ser copiado, distribuído, exibido, transmitido ou adaptado desde que citados, de forma clara e explícita, o nome da revista, a edição, o ano e as páginas nas quais o artigo foi publicado originalmente, mas sem sugerir que a RAM endosse a reutilização do artigo. Esse termo de licenciamento deve ser explicitado para os casos de reutilização ou distribuição para terceiros. Não é permitido o uso para fins comerciais.
} 


\section{ABSTRACT}

Purpose: To investigate the relationship between religious beliefs and the constructs of the Theory of Planned Behavior in entrepreneurial intention. Originality/value: The article stands out by promoting the understanding of entrepreneurship from the Theory of Planned Behavior proposed by Ajzen (1991), aligning it with religious beliefs.

Design/methodology/approach: It is an exploratory and descriptive study, of a quantitative nature. The survey method was used to collect the data, in which a sample of 448 students from the Business Administration courses at two public universities in the northeast of Brazil was obtained. Structural Equation Modeling was used to treat and analyze the data.

Findings: The results demonstrated that personal attitude, perceived control, and religious beliefs influence the entrepreneurial intention of university students, which did not occur with subjective norms. However, subjective norms influenced the personal attitude and perceived control of university students. The university students presented a predisposition to entrepreneurship and recognized that they have the necessary skills to create a business. However, the choice to become an entrepreneur may not be motivated directly by the expectation of its social referents. Moreover, university students did not perceive the influence of religious beliefs in the manifestation of their behavior, because vocation and prosocial motivation are far from the environmental context in which university students are inserted or because they are not practicing a religion that fosters such beliefs.

\section{KEYWORDS}

Religious beliefs. Entrepreneurship. Entrepreneurial intention. Religion. Planned behavior. 


\section{INTRODUCTION}

Entrepreneurship is an emerging research field that has been stimulating academic interest in alternative ways that motivate the intention and entrepreneurial action (Paiva, Andrade, Antonialli, \& Brito, 2018; Smith, Conger, McMullen, \& Neubert, 2019). The legitimation of entrepreneurship as a research field promotes new directions for the expansion of investigations that integrate other fields of research with management (Busenitz, Plummer, Klotz, Shahzad, \& Rhoads, 2014), like religion, which facilitates the development of more transformational investigations, conceiving of new questions and insights (Baker \& Welter, 2017; Shepherd, 2015).

Religion manifests itself in entrepreneurship through religious beliefs, which influence the attitudes, intentions, and behaviors of individuals (Balog, Baker, \& Walker, 2014), and may encourage or discourage them from starting new businesses (Carswell \& Rolland, 2007; Wiseman \& Young, 2014). Also noteworthy is the association between religious beliefs and entrepreneurial intention, due to the inseparability between the entrepreneur, his environment, his interpersonal relationships and the resources available to achieve his goals (Serafim \& Feuerschütte, 2015).

Entrepreneurial intention is defined as the effort and encouragement that individuals have to perform entrepreneurial behavior under favorable conditions (Cantner, Goethner, \& Silbereisen, 2017; Souza, Santos, Lima, Cruz, \& Lezana, 2016). Thus, entrepreneurial intention has become the dominant perspective in the investigation of cognitive factors that may motivate the individual to act (Fayolle \& Liñán, 2014; Krueger, 2017; Paiva, Lima, Rebouças, Ferreira, \& Fontenele, 2018) through the use of theoretical models considered predominant in the field of studies related to entrepreneurship.

The theoretical model of entrepreneurial intention that is most used in the empirical and conceptual literature of entrepreneurship (Esfandiar, Sharifi-Tehrani, Pratt, \& Altinay, 2019; Fayolle \& Liñán, 2014; Martins, Santos, \& Silveira, 2019) is the Theory of Planned Behavior (TPB), developed by Ajzen (1991), which explains intent and behavior by means of three determining factors that predict them: 1 . personal attitude, that is, the favorable assessment to perform or not to perform the behavior; 2 . subjective norms, that is, the perceived social pressure to perform the behavior or not; and 3. perceived behavioral control, that is, the perceived easiness or difficulty in performing the behavior based on reflection of past experiences (Ajzen, 1991; Liñán \& Chen, 2009). 
From this perspective, and considering the alignment between religious beliefs and entrepreneurial intention, it was outlined as a goal to investigate the relationship between religious beliefs and the constructs of the TPB on entrepreneurial intention in a theoretical-empirical research context.

The discussion about the role of religion in shaping economic activities is attributed to Max Weber, who highlighted the contribution of protestant religious ethics to the emergence of capitalism as a contemporary mode of production (Stark, 2006), which culminated in the development of research that focus on investigating the interaction between entrepreneurship and the religious context and religious beliefs, as in the studies conducted by Audretsch, Boente, and Tamvada (2013), Balog et al. (2014), Rietveld and Van Burg (2014), Zelekha, Avnimelech, and Sharabi (2014), Borges, Enoque, Borges, and Almeida (2015), Parboteeah, Walter, and Block (2015), Serafim and Feuerschütte (2015), and Corrêa and Vale (2017).

The literature in the field of religious studies focuses mainly on investigating the influence of religion on the organizational environment and economic development in the religious scope (Corrêa \& Vale, 2017), and does not receive due attention in scientific investigations involving the relationship between entrepreneurship and religion (Audretsch et al., 2013; Borges et al., 2015; Corrêa \& Vale, 2017; Griebel, Park, \& Neubert, 2014; Rietveld \& Van Burg, 2014) when treated in the Brazilian context (Serafim, Martes, \& Rodriguez, 2012).

Understanding this relationship is a challenge for researchers in the field due to the limitations of existing conceptual frameworks, as few definitions are currently agreed upon. Moreover, the phenomenological approach predominates in existing research due to the exploratory nature of the field, which receives qualitative, conceptual and case-based studies, increasing the conceptual complexity of entrepreneurship (Balog et al., 2014; Smith et al., 2019). It is hoped, therefore, that this research may raise the interest of researchers in the area to use positivist and relational approaches between entrepreneurship and religion, so as to contribute to the construction of this field of scientific knowledge.

According to Borges et al. (2015), the interaction between entrepreneurship and issues associated with the religious field in Brazil has not been sufficiently explored in the sphere of organizational studies and entrepreneurship, since religious beliefs, as a source of motivation and opportunity for business creation, are considered to be under-investigated in the literature. Greater commitment to the development of scientific studies in this area of knowledge is therefore required. Corrêa, Vale, and Pinto (2018) also 
reinforce that the Brazilian religious context is a prolific field for the development of investigations and new findings for the entrepreneurship literature.

Given these approaches, this article aims to contribute to the understanding of entrepreneurial intention, which is the main phenomenon to understand the process of entrepreneurship, including religious beliefs, as they can help individuals identify specific business opportunities, as well as motivate them to develop entrepreneurial behaviors. This article is grounded in the conceptual framework of the TPB.

\section{THEORETICAL BACKGROUND}

\subsection{Entrepreneurial intention and the Theory of Planned Behavior}

Studies and discussions about entrepreneurial intention gained relevance during the last two decades of the twentieth century through the works of Shapero and Sokol (1982) and Davidsson (1995), as well as in the twentyfirst century, in the research conducted by Liñán and Chen (2009), Teixeira and Davey (2010), Bae, Qian, Miao, and Fiet (2014), Nabi, Liñán, Fayolle, Krueger, and Walmsley (2017), and Passaro, Quinto, and Thomas (2018).

Firstly, we emphasize the Theory of Rational Action of Ajzen and Fishbein (1977), which encouraged the Theory of Entrepreneurial Intentions (Shapero \& Sokol, 1982) and the TPB (Ajzen, 1991), the latter being characterized as the most used theoretical model to predict entrepreneurial intention (Esfandiar et al., 2019; Fayolle \& Liñán, 2014; Martins et al., 2019). Depending on TPB, human action is guided by beliefs that involve direct observation of a given object/attribute and the use of formal coding systems that comprise rules of logic (Ajzen, 1991; Liñán \& Chen, 2009). Ajzen (2011) argues that beliefs are rationally conceived and represent reality, reflecting the information an individual holds regarding a specific behavior, even if such information is inaccurate or does not reflect reality.

The intention is before entrepreneurial behavior (Ajzen, 1991) and refers to the business creation process (Krueger \& Carsrud, 1993). The entrepreneurial intention is considered to be something latent that needs to be awakened and improved for entrepreneurial behavior to be effective. The intention is the main predictor of behavior (Ajzen, 1991; Teixeira \& Davey, 2010), and this makes it possible to point out that the stronger the intention, the more likely the behavior is to manifest (Ajzen \& Fishbein, 1977; Ajzen, 
1991), characterizing the individual as a potential entrepreneur because his/her intention to act can be independent of the occurrences of profit or success (Souza, Coelho, Esteves, Lima, \& Santos, 2016).

Some studies have reinforced the relevance of TPB to measure entrepreneurial intention from its antecedents, namely, personal attitudes, subjective norms and perceived behavioral control (Costa \& Mares, 2016; Ferreira, Loiola, \& Gondim, 2017; Kautonen, Van Gelderen, \& Fink, 2015; Liñán \& Chen, 2009).

Personal attitudes refer to the degree of evaluation (positive or negative) that the individual undertakes before acting, and it considers advantages and evaluations through social pressure on the decision to become an entrepreneur (Ajzen, 1991). Cavazos-Arroyo, Puente-Díaz, and Agarwal (2017) consider that the behavioral beliefs of individuals influence the attitude towards entrepreneurial behavior since such beliefs suggest that positive results can be obtained by performing a certain behavior.

Thus, the behavior is guided by beliefs and customs when deciding whether to adopt a position (Ajzen, 1991; Autio, Kenney, Mustar, Siegel, \& Wright, 2014; Liñán \& Chen, 2009) and a favorable attitude is associated with a greater entrepreneurial intention (Liñán \& Chen, 2009). Moreover, results from empirical research conducted by Moriano, Gorgievski, Laguna, Stephan, and Zarafshani (2012), Zapkau, Schwens, Steinmetz, and Kabst (2015), and Oliveira, Vieira, Laguía, Moriano, and Soares (2016) have demonstrated that personal attitude exerted a positive influence on entrepreneurial intention. Because of these approaches, the following hypothesis arises:

- $\mathrm{H}_{1}$ : Personal attitude has a positive influence on entrepreneurial intention.

To investigate the other antecedents of the TPB model, the influence of subjective norms and perceived control on entrepreneurial intention was also verified. Subjective norms refer to beliefs arising from the social environment, through the influence of social groups (Cavazos-Arroyo et al., 2017), and measure the perceived social pressure to perform certain behaviors or not to perform certain behaviors, which emphasizes an individual's concern about the consequences of their behavior for other people (Ajzen, 1991).

Some authors, such as Kautonen, Van Gelderen, and Tornikoski (2013) and Zapkau et al. (2015), consider subjective norms the weakest construct to predict entrepreneurial intention, since the influence of social referents may 
not be sufficient to modify the behavioral beliefs and perceived control of potential entrepreneurs. However, research by Autio, Keeley Klosten, Parker, and Hay (2001), Moriano et al. (2012), Zapkau et al. (2015), and Oliveira et al. (2016) provided evidence of the positive influence of subjective norms on entrepreneurial intention. Therefore, the following hypotheses arise:

- $\mathrm{H}_{2}$ : Subjective norms have a positive influence on entrepreneurial intention.

- $\mathrm{H}_{3}$ : Subjective norms have a positive influence on personal attitude.

- $\mathrm{H}_{4}$ : Subjective norms exert a positive influence on perceived control.

Regarding perceived control, Cavazos-Arroyo et al. (2017) approach such a predictor as the belief of an individual in his ability to perform the functions and tasks essential to becoming an entrepreneur. According to Krueger and Brazeal (1994), perceived control is a prerequisite for a potential entrepreneur, due to the inexperience of novice entrepreneurs. The results of empirical research (Costa \& Mares, 2016; Liñán, Nabi, \& Krueger, 2013; Oliveira et al., 2016) have demonstrated that perceived control is a predictor of entrepreneurial intention. In this sense, the following hypothesis is proposed:

- $\mathrm{H}_{5}$ : Perceived control has a positive influence on entrepreneurial intention.

\subsection{Religion and religious beliefs}

Entrepreneurial activity is influenced by cultural and institutional factors, such as religion (Henley, 2017), which can affect individual characteristics, such as work ethic, honesty, economics, charity, and trust. Given the appreciation of these attributes, religiosity can encourage investment and economic growth (McCleary \& Barro, 2006).

Religious beliefs express information based on religious teachings, which are often taught and passed on between generations, affecting the individual's attitude and behavior toward the economic system (Guiso, Sampieza, \& Zingales, 2003). From the perspective of Rietveld and Van Burg (2014), religious vocation and prosocial motivation are considered as religious beliefs.

Vocation refers to a sense of purpose that incites the individual to personal and social involvement in the work, having as a parameter the transcendent or a feeling of passion (Duffy \& Dik, 2013). Thus, by being 
guided by the religious vocation, the entrepreneur can conduct his business and devote himself to divine purposes. In contrast, Thiry-Cherques (2009) clarifies that the rational organization of work and technology stimulated feelings of disenchantment and that work is no longer seen as a divine calling, leading to the removal of the religious sense of labor activities.

Another religious belief that can influence entrepreneurship refers to prosocial motivations, as the individual is encouraged to develop prosocial actions for the benefit of others (Johnmark, Soemunti, Laura, Munene, \& Balunywa, 2016). Prosocial motivations stimulated by religions are not observed by all practitioners, although some research has highlighted that religious Christians are more prone to prosocial and altruistic behavior than non-religious people (Rietveld \& Van Burg, 2014).

According to Namatovu, Dawa, Adewale, and Mulira (2018), religious beliefs can shape the behavior of entrepreneurs by contributing to entrepreneurial identities. The connection between religious beliefs, personal values, and entrepreneurial activity was investigated by Dougherty, Neubert, and Park (2019), who verify that religious beliefs act as a moderating variable in the relationship between personal values and entrepreneurial activity. Riaz, Farrukh, Rehman, and Ishaque (2016), in turn, found that religion has an impact on entrepreneurial intention, confirming that the more religious an individual is, the greater the likelihood of becoming entrepreneurial; this is corroborated by Johnmark et al. (2016) when they emphasize that religious beliefs predict entrepreneurial behavior.

Considering the empirical and conceptual literature on religious beliefs and entrepreneurial intention, one can highlight one more hypothesis for this research:

- $\mathrm{H}_{6}$ : Religious beliefs have a positive influence on entrepreneurial intention.

In line with previous scholarly approaches, we now present the research model, which was developed in consideration of the proposed hypotheses. The model focuses on the relationship between religious beliefs and the antecedents of entrepreneurial intention, based on the TPB (Figure 2.2.1). 


\section{(Figure 2.2.1) \\ RESEARCH MODEL}

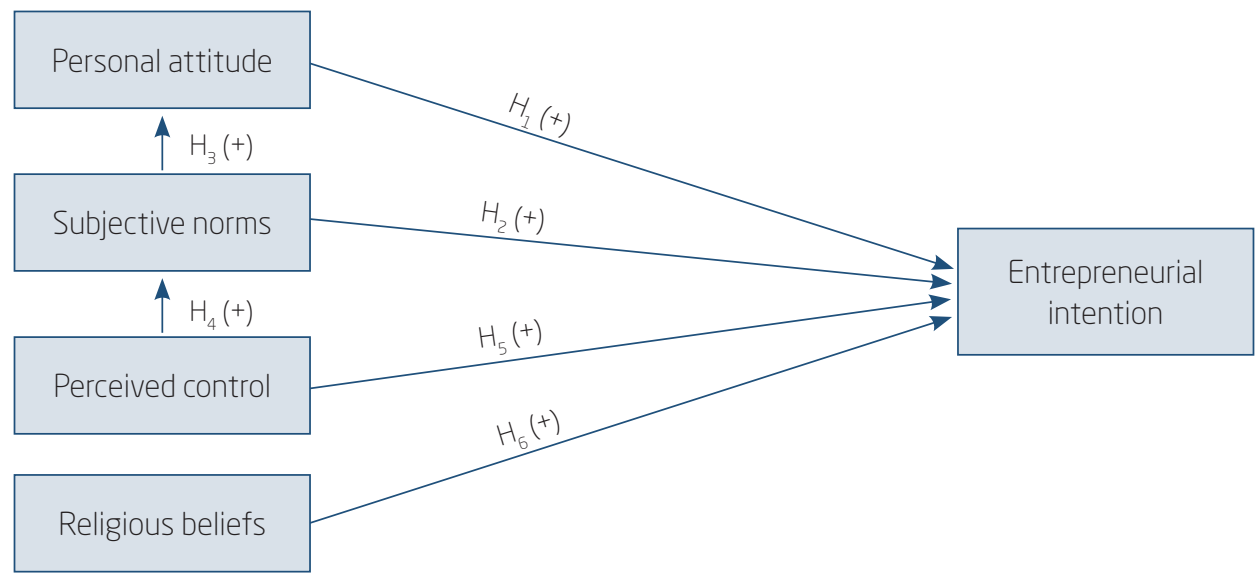

Source: Elaborated by the authors.

The proposed discussion sought to justify the adopted model and the relevant concepts for the development of the hypotheses, to suggest interconnections between the constructs adopted in the study. The following is the methodological design for obtaining the data analyzed in this research.

\section{METHODOLOGICAL PROCEDURES}

This study is guided by the positivist research paradigm. In Crotty's perspective (1998), paradigm refers to a philosophical instance that aims to inform the method used in the research. This is a quantitative, descriptive study using the survey method for data collection (Hair, Black, Babin, Anderson, \& Tatham, 2009). The population comprises undergraduate students in the Business Administration courses from two public universities in the northeast of Brazil, which offer disciplines related to entrepreneurship.

The entrepreneurial intention, manifesting itself in individuals who are predisposed to start businesses, holds the research base in the undergraduate students in Business Administration, because Rasli, Khan, Malekifar, and Jabeen (2013) and Ferreira et al. (2017) reinforce that this audience can be considered more educated and prone to entrepreneurship. Research that analyzes entrepreneurial intention among university students focuses mainly on the business area, due to the offers of entrepreneurship projects, and this justifies the choice of the target audience of this research. 
Within the research universe, based on a population of 1280 students from both universities investigated, a sample of 448 respondents was obtained, which demonstrated a return rate of $35 \%$ of the population, indicating that the sample is relevant to the size of the population investigated. Among the 448 individuals, 242 declared themselves men, 202 women and three of another gender. In terms of age, 186 individuals are between 16 and 20 years old, 175 are between 21 and 25 years old, 48 between 26 and 30 years old and 39 are over 31 years old, with a predominance of single people. Regarding religious affiliation, 219 are catholic, 106 have no religious affiliation, 87 are evangelicals, 23 are from other religions and 13 are spiritualists. Regarding the practice of religion, 246 are active practitioners of their religions; and 202 are non-practitioners of religion.

The instrument for data collection was developed by adapting validated scales in empirical and conceptual literature. These include the scale of religious beliefs, by Rietveld and Van Burg (2014), and the Entrepreneurial Intention Questionnaire, proposed by Liñán and Chen (2009), which is based on the TPB and measures personal attitude, subjective norms and perceived behavioral control. The final version of the data collection instrument contains 33 items, 28 of which were arranged on a five-point Likert scale, ranging from 1 (strongly disagree) to 5 (strongly agree), in order to measure the model dimensions, as shown in Figure 3.1, and with the other items sought to characterize the sample, considering the affiliation and religious practice, gender, age, and marital status.

\section{(Figure 3.1)}

\section{SEARCH INSTRUMENT ITEMS}

\begin{tabular}{|c|c|c|}
\hline Construct & Item & Assertive \\
\hline \multirow{6}{*}{$\begin{array}{l}\text { Entrepreneurial intention } \\
\qquad(\mathrm{IE})\end{array}$} & $\mid E 1$ & I am ready to do anything to be an entrepreneur. \\
\hline & IE2 & My professional goal is to become an entrepreneur. \\
\hline & IE3 & I will make every effort to start and run my own firm. \\
\hline & IE4 & I am determined to create a firm in the future. \\
\hline & IE5 & I have very seriously thought of starting a firm. \\
\hline & IE6 & I have the firm intention to start a firm someday. \\
\hline \multirow[t]{2}{*}{$\begin{array}{l}\text { Personal attitude } \\
\qquad(A P)\end{array}$} & AT1 & $\begin{array}{l}\text { In my opinion, being an entrepreneur implies more advantages } \\
\text { than disadvantages. }\end{array}$ \\
\hline & AT2 & A career as an entrepreneur seems attractive. \\
\hline
\end{tabular}




\section{(Figure 3.1 (conclusion))}

\section{SEARCH INSTRUMENT ITEMS}

\begin{tabular}{|c|c|c|}
\hline Construct & Item & Assertive \\
\hline \multirow[t]{3}{*}{$\begin{array}{l}\text { Personal attitude } \\
\qquad(A P)\end{array}$} & AT3 & $\begin{array}{l}\text { If I had the opportunity and the necessary resources, I would } \\
\text { like to start a company. }\end{array}$ \\
\hline & AT4 & Being an entrepreneur would make me very satisfied. \\
\hline & AT5 & $\begin{array}{l}\text { I would prefer to become an entrepreneur, even if I considered } \\
\text { other options. }\end{array}$ \\
\hline \multirow[t]{3}{*}{$\begin{array}{l}\text { Subjective norms } \\
\qquad(S N)\end{array}$} & NS1 & $\begin{array}{l}\text { My friends would approve of my decision to become an } \\
\text { entrepreneur. }\end{array}$ \\
\hline & NS2 & $\begin{array}{l}\text { My family would approve of my decision to become an } \\
\text { entrepreneur. }\end{array}$ \\
\hline & NS3 & $\begin{array}{l}\text { My college classmates would approve of my decision to } \\
\text { become an entrepreneur. }\end{array}$ \\
\hline \multirow{6}{*}{$\begin{array}{l}\text { Perceived control } \\
\qquad(\mathrm{CP})\end{array}$} & $\mathrm{CP} 1$ & To start a firm and keep it working would be easy for me. \\
\hline & CP2 & I am prepared to start a viable firm. \\
\hline & CP3 & I can control the creation process of a new firm. \\
\hline & CP4 & $\begin{array}{l}\text { I know how to develop an entrepreneurial project (a business } \\
\text { plan, for example). }\end{array}$ \\
\hline & CP5 & I know the necessary practical details to start a firm. \\
\hline & CP6 & $\begin{array}{l}\text { If I tried to start a firm, I would have a high probability of } \\
\text { succeeding. }\end{array}$ \\
\hline \multirow{8}{*}{$\begin{array}{l}\text { Religious beliefs } \\
\text { (RB) }\end{array}$} & CR1 & My faith influenced my professional choice. \\
\hline & CR2 & I see my professional choice as a divine vocation. \\
\hline & CR3 & My work, as a vocation, will make people love God. \\
\hline & CR4 & I will be conducted by God's tasks in my work. \\
\hline & CR5 & $\begin{array}{l}\text { I am keen to start my own business because it will } \\
\text { please God. }\end{array}$ \\
\hline & CR6 & My economic activity has a positive influence on society. \\
\hline & CR7 & $\begin{array}{l}\text { I understand that my religious beliefs are useful to society } \\
\text { due to my work/ life. }\end{array}$ \\
\hline & CR8 & It is always beneficial to conduct business by fearing God. \\
\hline
\end{tabular}

Source: Elaborated by the authors. 
Data collection was carried out in March and April 2018, by applying the questionnaire in the classroom, with students from all semesters of the Business Administration courses.

For descriptive statistics analysis, the Statistical Package for Social Sciences (SPSS) (version 22) software was used. Additionally, Structural Equation Modeling (SEM), built with the aid of SmartPLS 3.0 software, was adopted, using the reflective measurement model, whose consistency is assessed through its reliability and validity, focusing on the convergent and discriminating aspects (Afthanorhan, 2013).

\section{RESULTS AND ANALYSIS}

\subsection{Reliability and validity of the constructs}

Based on SEM, the factor loadings and their observed variables were analyzed to verify the relationship between these variables. The structural model is presented in Figure 4.1.1 and it is composed of the following constructs: personal attitude (AT), subjective norms (NS), perceived control (CCP), religious beliefs (CR), and entrepreneurial intention (IE), with the observed variables and their respective factor loads. The variables AT1, CP1, and CR6, belonging to the TPB constructs, were removed from the model because they presented factor loadings below 0.700, as recommended by Hair, Hult, Ringle, and Sarstedt (2016).

Subsequently, we proceeded to the second stage of analysis, consisting of the evaluation of the measurement model through the analysis of convergent validity, Cronbach's alpha, and $\mathrm{R}$ square. It was found that the average variance extracted (AVE) of the constructs meet the criteria of Fornell and Larcker (Henseler, Ringle, \& Sinkovics, 2009), as they presented values greater than 0.50 (AVE > 0.5), indicating a positive relationship between the variables and their respective constructs (Ringle, Silva, \& Bido, 2014), and this shows that the latent variable explains more than half of the indicator variations (Afthanorhan, 2013). This demonstrates that the model has convergent validity acceptable for the analysis.

Regarding the internal consistency criteria, the values of composite reliability and Cronbach's alpha were observed, indices used to assess whether the sample contains no bias and whether the response set is reliable (Ringle et al., 2014). The value of composite reliability refers to a Cronbach's alpha of above 0.7 , considered adequate for exploratory research, which allows us to infer that there is a significant internal consistency to measure 
the investigated constructs (Hair et al., 2016). Thus, there is interrelation in all constructs that make up the model, as shown in Figure 4.1.2.

(Figure 4.1.1)

STRUCTURAL ANALYSIS MODEL

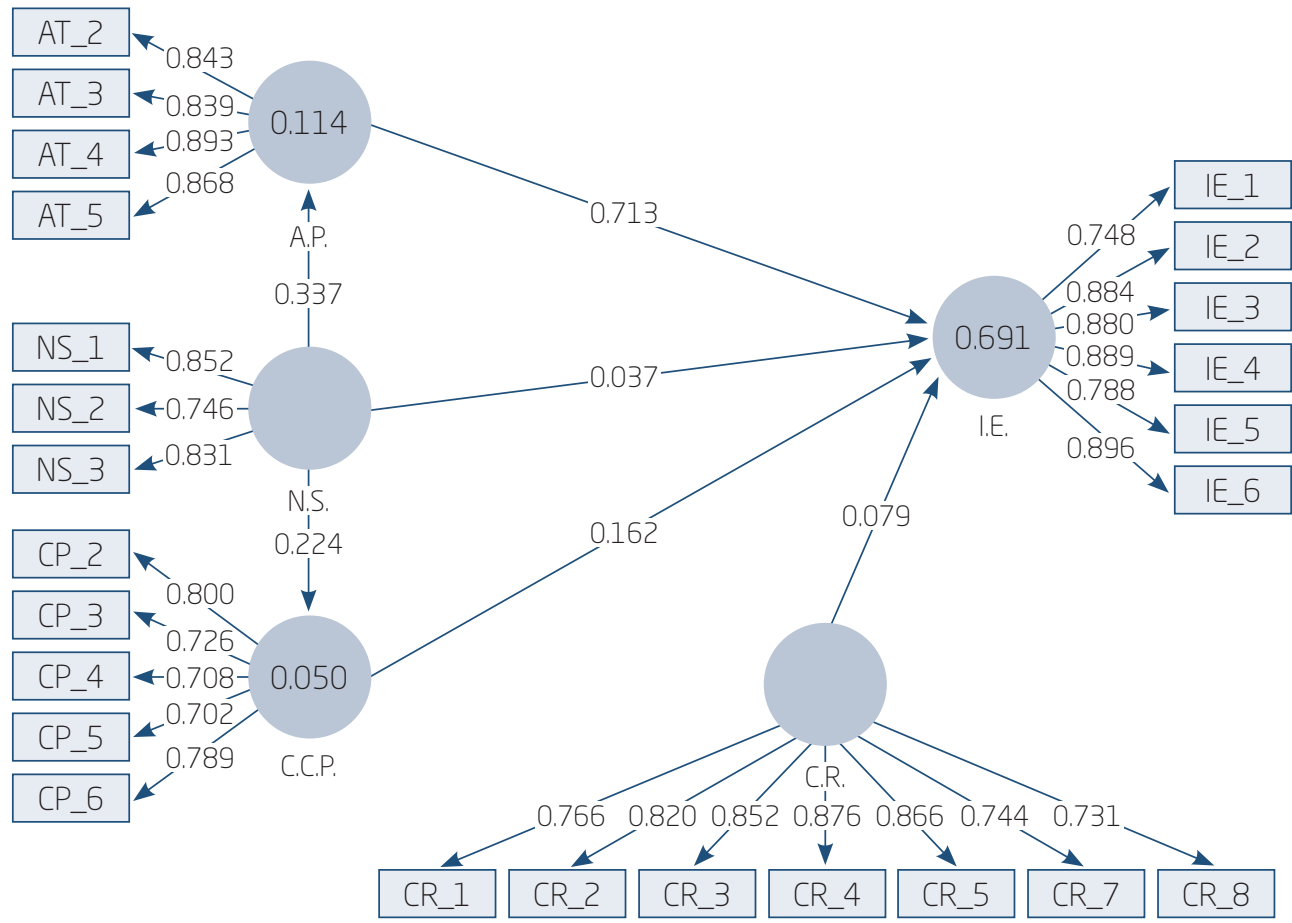

Source: Elaborated by the authors with SmartPLS.

(Figure 4.1.2)

ADJUSTMENT INDICATORS, CONVERGENT VALIDITY, AND RELIABILITY

\begin{tabular}{lcccc} 
Constructs & $\begin{array}{c}\text { Average variance } \\
\text { extracted } \\
\text { (AVE) }\end{array}$ & $\begin{array}{c}\text { Composite } \\
\text { reliability }\end{array}$ & $\begin{array}{c}\text { Cronbach's } \\
\text { alpha }\end{array}$ & $\begin{array}{c}\text { R } \\
\text { square }\end{array}$ \\
\hline Personal attitude & 0.741 & 0.920 & 0.883 & 0.114 \\
\hline Perceived control & 0.557 & 0.862 & 0.813 & 0.050 \\
\hline Subjective norms & 0.658 & 0.852 & 0.746 & \\
\hline Religious beliefs & 0.656 & 0.930 & 0.913 & \\
\hline Entrepreneurial intention & 0.721 & 0.939 & 0.922 & 0.691 \\
\hline
\end{tabular}

Source: Elaborated by the authors with SmartPLS. 
The R square value of 0.691 for entrepreneurial intention indicates that approximately $69 \%$ of the variance of the construct is explained by the antecedents identified in the model, while the $\mathrm{R}$ square of the personal attitude and perceived control constructs presented values of $11.4 \%$ and $5.0 \%$, respectively, indicating a small explanatory effect (Cohen, 1988) on causal relationships with entrepreneurial intention. It remained in the model, however, because it met the quality of fit requirements that were essential for the analyses.

The third stage involves the evaluation of the discriminant validity of the structural model (Ringle et al., 2014), adopting the criteria of Fornell and Larcker (1981), by comparing the square roots of the AVE values of each construct with Pearson's correlation between the latent variables.

In the main diagonal of Figure 4.1.3, the AVE values of the square roots were arranged, higher than the values in their rows and columns, and this shows that the model has discriminant validity (Fornell \& Larcker, 1981).

\section{(Figure 4.1.3)}

DISCRIMINANT VALIDITY INDICATORS FOR THE CONSTRUCTS

\begin{tabular}{lccccc}
\hline \multicolumn{1}{c}{ Constructs } & $\begin{array}{c}\text { Personal } \\
\text { attitude }\end{array}$ & $\begin{array}{c}\text { Perceived } \\
\text { control }\end{array}$ & $\begin{array}{c}\text { Religious } \\
\text { beliefs }\end{array}$ & $\begin{array}{c}\text { Entrepreneurial } \\
\text { intention }\end{array}$ & $\begin{array}{c}\text { Subjective } \\
\text { norms }\end{array}$ \\
\hline Personal attitude & 0.861 & & & & \\
\hline Perceived control & 0.431 & 0.746 & & & \\
\hline Religious beliefs & 0.205 & 0.224 & 0.810 & & \\
\hline Entrepreneurial intention & 0.811 & 0.495 & 0.267 & 0.849 & \\
\hline Subjective norms & 0.337 & 0.224 & 0.174 & 0.327 & 0.811 \\
\hline
\end{tabular}

Source: Elaborated by the authors with SmartPLS.

Since the discriminant validity result showed that the latent variables are independent, we continued to the next step: analysis of predictive validity $\left(\mathrm{Q}^{2}\right)$ and effect size $\left(\mathrm{f}^{2}\right)$.

\subsection{Predictive validity $\left(Q^{2}\right)$ and effect size $\left(f^{2}\right)$}

To verify the quality of the model, two indicators were analyzed: the Stone-Geisser $\left(\mathrm{Q}^{2}\right)$ indicator, which evaluates the predictive relevance of the model; and the Cohen indicator, which verifies the effect size $\left(f^{2}\right)$, that is, the relative importance of each construct in the model, through the blindfolding procedure. The reference values for the effect size $\left(\mathrm{f}^{2}\right)$ considered 
for the analysis are between 0.02 and 0.15 for small effects; between 0.15 and 0.35 for average effects; and over 0.35 for large effects (Hair, Sarstedt, Ringle, \& Mena, 2012).

The values of $\mathrm{Q}^{2}$ and $\mathrm{f}^{2}$ highlight that the model has prediction quality, as shown in Figure 4.2.1. Predictive relevance $\left(\mathrm{Q}^{2}\right)$ presented values greater than zero (personal attitude: 0.071; perceived control: 0.022; and entrepreneurial intention: 0.455 ), and thus, it can be concluded that the adjusted model has precision and that the most explained variable in the model was the entrepreneurial intention $\left(\mathrm{Q}^{2}=0.455\right)$. By analyzing the effect size $\left(\mathrm{f}^{2}\right)$, it was found that the constructs of perceived control and subjective norms had average effects on entrepreneurial intention. On the other hand, personal attitude $\left(f^{2}=0.469\right)$ and religious beliefs $\left(f^{2}=0.461\right)$ presented the greatest explanatory power in the model, with a significant effect on entrepreneurial intention.

(Figure 4.2.1)

PREDICTIVE VALIDITY (Q²) AND EFFECT SIZE (F²) INDICATORS

\begin{tabular}{lcc}
\hline & CV RED $\left(Q^{2}\right)$ & CV COM (f $\left.{ }^{2}\right)$ \\
\hline Personal attitude & 0.077 & 0.469 \\
\hline Perceived control & 0.021 & 0.306 \\
\hline Religious beliefs & & 0.461 \\
\hline Entrepreneurial intention & 0.460 & 0.538 \\
\hline Subjective norms & & 0.319 \\
\hline
\end{tabular}

Source: Elaborated by the authors with SmartPLS.

\subsection{Hypothesis test}

Regarding the evaluation of the structural model and the hypothesis test, the significance of the relationships in the model was observed through bootstrapping in order to verify the values of the students' t-tests and p-values. P values less than 0.05 or students' t-tests greater than 1.96 indicate statistical significance at the $5 \%$ level. The student t-test analyzes the hypothesis in which the correlation coefficients are zero. If the test results indicate values greater than 1.96, the null hypothesis is rejected, and the correlation is significant (Hair et al., 2012). To verify the significance of the $\beta$ coefficients, the bootstrapping was performed with a thousand of subsamples, with a significance level of $5 \%$. 
The path coefficient values of the structural model were interpreted as standard least-squares regression coefficients $(\beta)$. It is also possible to verify the regression coefficients associated with each of the observed variables (AT, NS, CP, and CR) and how they impact on the latent variable (IE).

The analysis of the model revealed significant paths between the constructs, and this confirmed four hypotheses of the study (adopted in the research model). Figure 4.3.1 shows the values of the Students' t-tests and p-values, which take into account the relationship between all model variables and the standardized regression coefficients.

(Figure 4.3.1)

FINAL STRUCTURAL INDICATORS

\begin{tabular}{clccc}
\hline Hypotheses & \multicolumn{1}{c}{ Structural path } & t-value & p-value & Coefficient $\beta$ \\
\cline { 2 - 5 }$H_{1}$ & Personal attitude- > entrepreneurial intention & 29.44 & 0.000 & 0.713 \\
\hline$H_{2}$ & Subjective norms- > entrepreneurial intention & 1.517 & 0.065 & 0.031 \\
\hline$H_{3}$ & Subjective norms- > personal attitude & 7.943 & 0.000 & 0.348 \\
\hline$H_{4}$ & Subjective norms-> perceived control & 5.020 & 0.000 & 0.234 \\
\hline$H_{5}$ & Perceived control-> entrepreneurial intention & 5.326 & 0.000 & 0.152 \\
\hline$H_{6}$ & Religious beliefs-> entrepreneurial intention & 3.076 & 0.001 & 0.072 \\
\hline
\end{tabular}

Source: Elaborated by the authors with SmartPLS.

Personal attitude presented the highest regression coefficient with the entrepreneurial intention variable $(\beta=0.713)$, that is, when it increases a unit, its major contribution comes from personal attitude. The perceived control variables $(\beta=0.152)$ and religious beliefs $(\beta=0.072)$ presented a weak and positive relationship with the entrepreneurial intention variable. Thus, the variables observed - personal attitude, perceived control and religious beliefs - exerted influence on entrepreneurial intention.

Through the structural model, the following conclusions were obtained about the hypotheses proposed in the research model:

a) Personal attitude had a positive influence on entrepreneurial intention, presenting a p-value less than 0.05 , which allows us to support $\mathrm{H}_{1}$.

b) The relationship between the constructs' subjective norms and the entrepreneurial intention was not supported by the PLS algorithm ( $\mathrm{t}$ value $<1.96$ ), thus, refuting hypothesis $\mathrm{H}_{2}$. 
c) It was verified, however, that the subjective norms exerted a positive influence on personal attitude (p-value less than 0.05) and perceived control (p-value less than 0.05), thus supporting hypotheses $\mathrm{H}_{3}$ and $\mathrm{H}_{4}$, respectively.

d) The relationship between the constructs' perceived control and the entrepreneurial intention was confirmed by presenting a p-value less than 0.05 , providing evidence to support $\mathrm{H}_{5}$.

e) Religious beliefs had a positive influence on entrepreneurial intention, evidenced by a p-value less than 0.05 , which supported $\mathrm{H}_{6}$.

\subsection{Discussion of results}

This research becomes pertinent because it allows for a broader panorama of the influence of predictors of entrepreneurial intention when considering the TPB (Ajzen, 1991), with the additional influence of religious beliefs on entrepreneurial intention of university students. This expands current research to align entrepreneurial intention with religious beliefs, which contributes to the empirical and conceptual literature of entrepreneurship and religion.

Through empirical research with a quantitative approach, the results indicated that personal attitude influenced the entrepreneurial intention of college students. In this sense, $\mathrm{H}_{1}$ can be supported, and this is in line with the research of Oliveira et al. (2016), and Schaefer, Nishi, Grohmann, Löbler, and Minello (2017), showing that the attitude of undergraduate students influenced the formation of entrepreneurial intention.

However, the subjective norms did not present statistically significant coefficients in the research model, indicating the non-support of $\mathrm{H}_{2}$, as the social referents had no influence on the students' intention to become entrepreneurial, which corroborates the work of Autio et al. (2001). Given this result, Ajzen's perspective $(1991,2011)$ is elucidated, since the relevance of predictors varies due to certain situations and behaviors, and the influence of subjective norms can be associated with uncontrolled personal variables, such as the locus of internal control or strong action orientation (Krueger, Reilly, \& Carsrud, 2000). The findings of Krueger et al. (2000) and Liñán et al. (2013) indicated that the subjective norm is the least influential predictor of entrepreneurial intention formation, exerting effects on personal attitude and perceived control. This supported hypotheses $\mathrm{H}_{3}$ and $\mathrm{H}_{4}$.

Perceived control influenced entrepreneurial intent, supporting $\mathrm{H}_{5}$, and this coincides with research by Liñán et al. (2013), Costa and Mares (2016) 
and Oliveira et al. (2016). According to Liñán et al. (2013), this result indicates that an environment of uncertainty, but one that is favorable to entrepreneurship, contributes to making students feel encouraged to become entrepreneurs, leading to a greater entrepreneurial intention.

Religious beliefs have influenced the entrepreneurial intention of students, and this is in line with research conducted by Johnmark et al. (2016) and Riaz et al. (2016), in which religious beliefs also significantly and positively influenced the entrepreneurial intention of students, supporting hypothesis $\mathrm{H}_{6}$. It is noteworthy that the overall fit adequacy index of the goodness-of-fit (GOF) model was not calculated, as Henseler and Sarstedt (2013) argue that the GOF model has little sensitivity for general evaluation of the structural model.

Given the results, Figure 4.4.1 summarizes the research hypotheses, with the expected and observed values, according to the adopted model, from which it is verified that only one of the hypotheses $\left(\mathrm{H}_{2}\right)$ was not supported.

\section{(Figure 4.4.1)}

VALUES OBSERVED IN THE HYPOTHESES

\begin{tabular}{ll}
\hline \multicolumn{1}{c}{ Hypotheses } & Observed value \\
\hline $\mathrm{H}_{1}$ : Personal attitude has a positive influence on entrepreneurial intention. & Supported \\
\hline $\mathrm{H}_{2}$ : Subjective norms have a positive influence on entrepreneurial intention. & Not supported \\
\hline $\mathrm{H}_{3}$ : Subjective norms have a positive influence on personal attitude. & Supported \\
\hline $\mathrm{H}_{4}$ : Subjective norms exert a positive influence on perceived control. & Supported \\
\hline $\mathrm{H}_{5}$ : Perceived control has a positive influence on entrepreneurial intention. & Supported \\
\hline $\mathrm{H}_{6}$ : Religious beliefs have a positive influence on entrepreneurial intention. & Supported \\
\hline
\end{tabular}

Source: Elaborated by the authors.

\section{CONCLUSIONS}

This study aimed to investigate the relationship between religious beliefs and the constructs of the TPB in entrepreneurial intention. As methodological bases, we used the models of religious beliefs developed by Rietveld and Van Burg (2014), and the entrepreneurial intention questionnaire proposed by Liñán and Chen (2009), containing indicators of adjustment to the reality of the research. It is possible to obtain results with 
important conclusions for the field of scientific knowledge related to entrepreneurship and religion, and specifically to entrepreneurial intention and religious beliefs.

There are empirical relationships between personal attitude, perceived control and religious beliefs in the entrepreneurial intent of university students. Personal attitude was the construct that had the greatest influence on entrepreneurial intention, showing that undergraduates make a favorable assessment of becoming entrepreneurial, presenting a predisposition to entrepreneurship. Furthermore, perceived control influenced entrepreneurial intention, but it did so to a lesser extent, which indicated that university students recognize that they have the necessary skills for business creation.

Religious beliefs had a weak influence on entrepreneurial intent because vocation and prosocial motivation are far from the environmental context in which university students are inserted, or because they are not practitioners of a religion that fosters such beliefs. It is possible, therefore, that university students do not realize the influence of religious beliefs on the manifestation of their behavior since religion can strengthen the individual's inclination toward entrepreneurship, or dissuade the individual away from entrepreneurship.

Moreover, subjective norms had direct influences only on personal attitude and perceived control, which allowed us to infer that university students are indirectly influenced by their social referents, through their perceptions of predisposition and viability, and that their choice to become entrepreneurs may not be directly motivated by the expectations of family members, friends or others who are considered important in their lives.

This research contributes to the existing literature on entrepreneurship by adding religious beliefs as one of the antecedents of entrepreneurial intention, as well as reinforcing the TPB, proposed by Ajzen (1991), as an appropriate theoretical model to measure intention, which manifests itself from beliefs, motivations, and values, among which are religious beliefs. As a methodological contribution, this research used the quantitative research method and hypothetical-deductive logic, considering that the positivist paradigm has been little used in research carried out in the national context relating to entrepreneurship and religion.

Another contribution of this study is to supporting entrepreneurship education. Higher education institutions can encourage entrepreneurial behavior through entrepreneurship education, fostering the development of skills so that their university students can become involved in entrepreneurship, allowing them to enter the world of work and also to generate jobs and income for the population. 


\section{COMPORTAMENTO PLANEJADO E CRENÇAS RELIGIOSAS COMO ANTECEDENTES DA INTENÇÃO EMPREENDEDORA: UM ESTUDO COM UNIVERSITÁRIOS}

) RESUMO

Objetivo: Este estudo teve como objetivo investigar o relacionamento entre as crenças religiosas e os constructos da Teoria do Comportamento Planejado na intenção empreendedora.

Originalidade/valor: $\mathrm{O}$ artigo se destaca por fomentar a compreensão do empreendedorismo a partir da Teoria do Comportamento Planejado, proposta por Ajzen (1991), alinhando-a com as crenças religiosas.

Design/metodologia/abordagem: Trata-se de um estudo exploratório e descritivo de natureza quantitativa. Adotou-se o método survey para a coleta dos dados, em que foi obtida uma amostra de 448 estudantes do curso de Administração de duas universidades públicas do Nordeste. Utilizou-se a modelagem de equações estruturais para o tratamento e a análise dos dados.

Resultados: Os resultados apontaram que a atitude pessoal, o controle percebido e as crenças religiosas exerceram influência sobre a intenção empreendedora de estudantes universitários, o que não ocorreu com as normas subjetivas. Contudo, as normas subjetivas influenciaram a atitude pessoal e o controle percebido dos estudantes universitários. Os universitários apresentaram uma predisposição ao empreendedorismo e reconheceram que têm as competências necessárias para criação de negócios. Contudo, a escolha em se tornar empreendedor pode não ser motivada, diretamente, pela expectativa de seus referentes sociais. Ademais, os universitários não perceberam a influência das crenças religiosas na manifestação do seu comportamento, pelo fato de a vocação e a motivação pró-social estarem distantes do contexto ambiental em que os universitários estão inseridos ou por não serem praticantes de uma religião que fomente tais crenças.

\section{$\int$ PALAVRAS-CHAVE}

Crenças religiosas. Empreendedorismo. Intenção empreendedora. Religião. Comportamento planejado. 


\section{REFERENCES}

Afthanorhan, W. M. A. B. W. (2013). A comparison of partial least square structural equation modeling (PLS-SEM) and covariance-based structural equation modeling (CB-SEM) for confirmatory factor analysis. International Journal of Engineering Science and Innovative Technology, 2(5), 198-205.

Ajzen, I. (1991). The theory of planned behavior. Organizational Behavior and Human Decision Processes, 50(2), 179-211. doi:10.1016/0749-5978(91) 90020-T

Ajzen, I. (2011). Behavioral interventions: Design and evaluation guided by the theory of planned behavior. In M. M. Mark, S. I. Donaldson, \& B. Campbell (Eds.). Social psychology and evaluation (pp. 71-101). New York: Guilford Press.

Ajzen, I., \& Fishbein, M. (1977). Attitude-behavior relations: A theoretical analysis and review of empirical research. Psychological Bulletin, 84(5), 888-918. doi:10.1037/0033-2909.84.5.888

Audretsch, D. B., Boente, W., \& Tamvada, J. P. (2013). Religion, social class, and entrepreneurial choice. Journal of Business Venturing, 28(6), 774-789. doi: 10.1016/j.jbusvent.2013.06.002

Autio, E., Kenney, M., Mustar, P., Siegel, D., \& Wright, M. (2014). Entrepreneurial innovation: The importance of context. Research Policy, 43 (7), 1097-1108. doi: 10.1016/j.respol.2014.01.015

Autio, E., Keeley, R. H., Klofsten, M., Parker, G. C., \& Hay, M. (2001). Entrepreneurial intent among students in Scandinavia and in the USA. Enterprise and Innovation Management Studies, 2(2), 145-160. doi:10.1080/ 14632440110094632

Bae, T. J., Qian, S., Miao, C., \& Fiet, J. O. (2014). The relationship between entrepreneurship education and entrepreneurial intentions: A metaanalytic review. Entrepreneurship Theory and Practice, 38(2), 217-254. doi:10. 1111/etap.12095

Baker, T., \& Welter, F. (2017). Come on out of the ghetto, please! Building the future of entrepreneurship research. International Journal of Entrepreneurial Behavior E Research, 23(2), 170-184. doi:10.1108/IJEBR-02-2016-0065

Balog, A. M., Baker, L. T., \& Walker, A. G. (2014). Religiosity and spirituality in entrepreneurship: A review and research agenda. Journal of Management, Spirituality \& Religion, 11 (2), 159-186. doi:10.1080/14766086.2013.836127 
Borges, A. F., Enoque, A. G., Borges, J. F., \& Almeida, L. L. S. (2015). Empreendedorismo religioso: Um estudo sobre empresas que exploram o nicho da religiosidade. Revista de Administração Contemporânea, 19(5) 565-583. doi:10.1590/1982-7849rac20151626

Busenitz, L. W., Plummer, L. A., Klotz, A. C., Shahzad, A., \& Rhoads, K. (2014). Entrepreneurship research (1985-2009) and the emergence of opportunities. Entrepreneurship, Theory and Practice, 38(5), 1-20. doi:10.11 11/etap. 12120

Cantner, U., Goethner, M., \& Silbereisen, R. K. (2017). Schumpeter's entrepreneur - a rare case. Journal of Evolutionary Economics, 27(1), 187-214. doi:10.1007/s00191-016-0467-3

Carswell, P., \& Rolland, D. (2007). Religion and entrepreneurship in New Zealand. Journal of Enterprising Communities: People and Places in the Global Economy, 1 (2), 162-174. doi:10.1108/17506200710752584

Cavazos-Arroyo, J., Puente-Díaz, R., \& Agarwal, N. (2017). Análise de alguns antecedentes da intenção empreendedora social entre os residentes do México. Revista Brasileira de Gestão de Negócios, 19(64), 180-199. doi:10. 7819/rbgn.v19i64.3129

Cohen, J. (1988). Statistical power analysis for the behavioral sciences (2nd ed.). New York: Psychology Press.

Corrêa, V. S., \& Vale, G. M. V. (2017). Ação econômica e religião: Igrejas como empreendimentos no Brasil. Revista de Administração Contemporânea, 21 (1), 1-18. doi:10.1590/1982-7849rac2017150144

Corrêa, V. S., Vale, G. M. V., \& Pinto, M. D. R. (2018). Acoplamento e desacoplamento sociais: Pastores como empreendedores. Revista de Administração de Empresas, 58(2), 188-200. doi:10.1590/s0034-759020180207

Costa, T. G., \& Mares, P. (2016). Factors affecting students' entrepreneurial intentions of Polytechnic Institute of Setubal: A cognitive approach. Revista de Administração, Contabilidade e Economia da Fundace, 7(1), 102-117. doi:10. 13059/racef.v7i1.175

Crotty, M. (1998). The foundations of social research: Meaning and perspective in the research process. London: Sage.

Davidsson, P. (1995). Culture, structure and regional levels of entrepreneurship.Entrepreneurship \& Regional Development, 7(1), 41-62. doi:10.1080/089 85629500000003

Dougherty, K. D., Neubert, M. J., \& Park, J. Z. (2019). Prosperity beliefs and value orientations: Fueling or suppressing entrepreneurial activity. Journal for the Scientific Study of Religion (forthcoming), 1-19. doi:10.1111/jssr. 12598 
Duffy, R. D., \& Dik, B. J. (2013). Research on calling: What have we learned and where are we going? Journal of Vocational Behavior, 83 (3), 428-436. doi:10.1016/j.jvb.2013.06.006

Esfandiar, K., Sharifi-Tehrani, M., Pratt, S., \& Altinay, L. (2019). Understanding entrepreneurial intentions: A developed integrated structural model approach. Journal of Business Research, 94, 172-182. doi:10.1016/j. jbusres.2017.10.045

Fayolle, A., \& Liñán, F. (2014). The future of research on entrepreneurial intentions. Journal of Business Research, 67(5), 663-666. doi:10.1016/j. jbusres.2013.11.024

Ferreira, A. D. S. M., Loiola, E., \& Gondim, S. M. G. (2017). Preditores individuais e contextuais da intenção empreendedora entre universitários: Revisão de literatura. Cadernos EBAPE.BR, 15(2), 292-308. doi:10.1590/1679395159595

Fornell, C., \& Larcker, D. F. (1981). Structural equation models with unobservable variables and measurement error: Algebra and statistics. Journal of Marketing Research, 18(3), 382-388. doi:10.2307/3150980

Griebel, J. M., Park, J. Z., \& Neubert, M. J. (2014). Faith and work: An exploratory study of religious entrepreneurs. Religions, 5(3), 780-800. doi: $10.3390 /$ rel5030780

Guiso, L., Sapienza, P., \& Zingales, L. (2003). People's opium? Religion and economic attitudes. Journal of Monetary Economics, 50(1), 225-282. doi:10.10 16/S0304-3932(02)00202-7

Hair, J. F., Black, W. C., Babin, B. J., Anderson, R. E., \& Tatham, R. L. (2009). Análise multivariada de dados. Porto Alegre: Bookman.

Hair, J. F., Hult, G. T. M., Ringle, C., \& Sarstedt, M. (2016). A primer on partial least squares structural equation modeling (PLS-SEM). Los Angeles: Sage.

Hair, J. F., Sarstedt, M., Ringle, C. M., \& Mena, J. A. (2012). An assessment of the use of partial least squares structural equation modeling in marketing research. Journal of the Academy of Marketing Science, 40(3), 414-433. doi:10. 1007/s11747-011-0261-6

Henley, A. (2017). Does religion influence entrepreneurial behaviour? International Small Business Journal, 35(5), 597-617. doi:10.1177/026624 2616656748

Henseler, J., Ringle, C. M., \& Sinkovics, R. R. (2009). The use of partial least squares path modeling in international marketing. Advances in International Marketing, 20, 277-319. doi: 10.1108/S1474-7979(2009)0000020014 
Henseler, J., \& Sarstedt, M. (2013). Goodness-of-fit indices for partial least squares path modeling. Computational Statistics, 28(2), 565-580. doi:10.10 07/s00180-012-0317-1

Johnmark, D. R., Soemunti, T. W., Laura, O., Munene, J. C., \& Balunywa, W. (2016). Disabled students' entrepreneurial action: The role of religious beliefs. Cogent Business \& Management, 3(1), 1-13.

Kautonen, T., Van Gelderen, M., \& Fink, M. (2015). Robustness of the theory of planned behavior in predicting entrepreneurial intentions and actions. Entrepreneurship Theory and Practice, 39(3), 655-674. doi:doi.org/10.1111/ etap. 12056

Kautonen, T., Van Gelderen, M., \& Tornikoski, E. T. (2013). Predicting entrepreneurial behaviour: A test of the theory of planned behaviour. Applied Economics, 45(6), 697-707. doi:10.1080/00036846.2011.610750

Krueger, N. F. (2017). Entrepreneurial intentions are dead: Long live entrepreneurial intentions. In M. Brännback \& A. L. Carsrud (Eds). Revisiting the entrepreneurial mind (pp. 13-34). Switzerland: Springer, Cham.

Krueger, N. F., \& Brazeal, D. V. (1994). Entrepreneurial potential and potential entrepreneurs. Entrepreneurship Theory and Practice, 18 (3), 91-104. doi: $10.1177 / 104225879401800307$

Krueger, N. F., \& Carsrud, A. L. (1993). Entrepreneurial intentions: Applying the theory of planned behaviour. Entrepreneurship \& Regional Development, 5(4), 315-330.

Krueger, N. F., Reilly, M. D., \& Carsrud, A. L. (2000). Competing models of entrepreneurial intentions. Journal of Business Venturing, 15(5-6), 411-432. doi:10.1016/S0883-9026(98)00033-0

Liñán, F., \& Chen, Y. W. (2009). Development and cross-cultural application of a specific instrument to measure entrepreneurial intentions. Entrepreneurship TheoryandPractice, 33(3), 593-617.doi:10.1111/j. 1540-6520.2009.00318.x

Liñán, F., Nabi, G., \& Krueger, N. (2013). British and Spanish entrepreneurial intentions: A comparative study. Revista de Economía Mundial, 33, 73-103.

Martins, F. S., Santos, E. B. A., \& Silveira, A. (2019). Intenção empreendedora: Categorização, classificação de construtos e proposição de modelo. Brazilian Business Review, 16(1), 46-62. doi:10.15728/bbr.2019.16.1.4

McCleary, R. M., \& Barro, R. J. (2006). Religion and economy. Journal of Economic Perspectives, 20(2), 49-72. doi:10.1257/jep.20.2.49

Moriano, J. A., Gorgievski, M., Laguna, M., Stephan, U., \& Zarafshani, K. (2012). A cross-cultural approach to understanding entrepreneurial intention. Journal of Career Development, 39(2), 162-185. doi:10.1177/08948 453 10384481 
Nabi, G., Liñán, F., Fayolle, A., Krueger, N., \& Walmsley, A. (2017). The impact of entrepreneurship education in higher education: A systematic review and research agenda. Academy of Management Learning \& Education, 16(2), 277-299. doi: 10.5465/amle.2015.0026

Namatovu, R., Dawa, S., Adewale, A., \& Mulira, F. (2018). Religious beliefs and entrepreneurial behaviors in Africa: A case study of the informal sector in Uganda. Africa Journal of Management, 4(3), 259-281. doi:10.1080/ 23322373.2018.1516939

Oliveira, B. M. F., Vieira, D. A., Laguía, A., Moriano, J. A., \& Soares, V. J. S. (2016). Intenção empreendedora em estudantes universitários: Adaptação e validação de uma escala (QIE). Avaliação Psicológica, 15(2), 187-196. doi:10.15689/ap.2016.1502.07

Paiva, A. L., Andrade, D. M., Antonialli, L. M., \& Brito, M. J. (2018). Strategic entrepreneurship: Observations from the practices of cachaça certification. Revista de Administração Mackenzie, 19(2), 1-24. doi:10.1590/16786971/eramg180099

Paiva, L. E. B., Lima, T. C. B., Rebouças, S. M. D. P., Ferreira, E. M. D. M., \& Fontenele, R. E. S. (2018). Influência da sustentabilidade e da inovação na intenção empreendedora de universitários brasileiros e portugueses. Cadernos EBAPE.BR, 16(4), 732-747. doi: 10.1590/1679-395167527

Parboteeah, K. P., Walter, S. G., \& Block, J. H. (2015). When does Christian religion matter for entrepreneurial activity? The contingent effect of a country's investments into knowledge. Journal of Business Ethics, 130(2), 447-465.

Passaro, R., Quinto, I., \& Thomas, A. (2018). The impact of higher education on entrepreneurial intention and human capital. Journal of Intellectual Capital, 19(1), 135-156. doi:10.1108/JIC-04-2017-0056

Rasli, A., Khan, S. U. R., Malekifar, S., \& Jabeen, S. (2013). Factors affecting entrepreneurial intention among graduate students of Universiti Teknologi Malaysia. International Journal of Business and Social Science, 4(2), 182-188.

Riaz, Q., Farrukh, M., Rehman, S., \& Ishaque, A. (2016). Religion and entrepreneurial intentions: An empirical investigation, International Journal of Advanced and Applied Sciences, 3(9), 31-36. doi:10.21833/ijaas.2016.09.006

Rietveld, C. A., \& Van Burg, E. (2014). Religious beliefs and entrepreneurship among Dutch protestants. International Journal of Entrepreneurship and Small Business, 23 (3), 279-295. doi:10.1504/IJESB.2014.065515

Ringle, C. M., Silva, D., \& Bido, D. D. S. (2014). Modelagem de equações estruturais com utilização do SmartPLS. Revista Brasileira de Marketing, 13(2), 56-73. doi: 10.5585/remark.v13i2.2717 
Schaefer, R., Nishi, J. M., Grohmann, M. Z., Löbler, M. L., \& Minello, Í. F. (2017). Valores pessoais, atitudes e intenção empreendedora: Um estudo com estudantes de graduação em administração. Revista Economia \& Gestão, 17(47), 123-143. doi:10.5752/P.1984-6606.2017v17n47p123

Serafim, M. C., \& Feuerschütte, S. G. (2015). Movido pelo transcendente: A religiosidade como estímulo ao "espírito empreendedor". Cadernos EBAPE. BR, 13(1), 165-182. doi: 10.1590/1679-39519058

Serafim, M. C., Martes, A. C. B., \& Rodriguez, C. H. L. (2012). "Segurando na mão de Deus": Organizações religiosas e apoio ao empreendedorismo. Revista de Administração de Empresas, 52 (2), 217-231. doi:10.1590/S003475902012000200008

Shapero, A., \& Sokol, L. (1982). The Social Dimensions of Entrepreneurship. In C. A. Kent, D. L. Sexton, \& K. H. Vesper (Eds.). Encyclopedia of Entrepreneurship (pp. 72-90). Englewood Cliffs, NJ: Prentice-Hall.

Shepherd, D. A. (2015). Party On! A call for entrepreneurship research that is more interactive, activity-based, cognitively hot, compassionate, and prosocial. Journal of Business Venturing, 30(4), 489-507. doi:10.1016/j. jbusvent. 2015.02.001

Smith, B. R., Conger, M. J., McMullen, J. S., \& Neubert, M. J. (2019). Why believe? The promise of research on the role of religion in entrepreneurial action. Journal of Business Venturing Insights, 11, e00119. doi:10.1016/j. jbvi.2019.e00119

Souza, G. H. S., Coelho, J. A. P. M., Esteves, G. G. L., Lima, N. C., \& Santos, P. D. C. F. (2016). Inventário de barreiras e facilitadores ao empreendedorismo: Construção e validação de um instrumento. Revista Eletrônica de Administração, 22(3), 381-412. doi:10.1590/1413-2311.04315.57744

Souza, G. H. S., Santos, P. D. C. F., Lima, N. C., Cruz, N. J. T., \& Lezana, Á. G. R. (2016). O potencial empreendedor e o sucesso empresarial: Um estudo sobre elementos de convergência e explicação. Revista de Administração Mackenzie, 17(5), 188-215. doi:10.1590/1678-69712016/administracao. v17n5p188-215

Stark, R. (2006). Economics of religion. In R. A. Segal (Ed.). The Blackwell companion to the study of religion (pp. 47-68). Australia: John Wiley \& Sons.

Teixeira, A. A., \& Davey, T. (2010). Attitudes of higher education students to new venture creation: The relevance of competencies and contextual factors. Industry and Higher Education, 24(5), 323-341. doi:10.5367/ihe. 2010.0005 
Thiry-Cherques, H. R. (2009). Max Weber: O processo de racionalização e o desencantamento do trabalho nas organizações contemporâneas. Revista de Administração Pública, 43(4), 897-918. doi:10.1590/S0034-76122009000 400007

Wiseman, T., \& Young, A. (2014). Religion: productive or unproductive? Journal of Institutional Economics, 10(1), 21-45. doi:10.1017/S1744137413 00026X

Zapkau, F. B., Schwens, C., Steinmetz, H., \& Kabst, R. (2015). Disentangling the effect of prior entrepreneurial exposure on entrepreneurial intention. Journal of Business Research, 68(3), 639-653. doi:10.1016/j.jbusres.2014. 08.007

Zelekha, Y., Avnimelech, G., \& Sharabi, E. (2014). Religious institutions and entrepreneurship. Small Business Economics, 42(4), 747-767.

\section{NOTAS DOS AUTORES}

Luis E. B. Paiva, master by the Faculty of Economics, Administration, Actuarial and Accounting, Federal University of Ceará (UFC); Evangelina S. Sousa, PhD by the Faculty of Economics, Administration, Actuarial and Accounting, Federal University of Ceará (UFC); Tereza C. B. Lima, PhD by the School of Education, Federal University of Ceará (UFC); Dirceu da Silva, PhD by the School of Education, São Paulo University (USP).

Luis E. B. Paiva is now PhD student in Administration and Controllership at Federal University of Ceará (UFC); Evangelina S. Sousa is now egress in Administration and Controllership at Federal University of Ceará (UFC); Tereza C. B. Lima is now professor at the Faculty of Economics, Administration, Actuarial and Accounting of Federal University of Ceará (UFC); Dirceu da Silva is now professor at the School of Education of Campinas State University (Unicamp).

Correspondence concerning this article should be addressed to Luis E. B. Paiva, Avenida da Universidade, 2431, Benfica, Fortaleza, Ceará, Brazil, CEP 60020-180.

E-mail: edubrandas@gmail.com

EDITORIAL BOARD

Editors-in-chief Janette Brunstein

Silvia Marcia Russi De Domênico

Associated Editor

Simone Costa Nunes

Technical Support

Vitória Batista Santos Silva

\section{EDITORIAL PRODUCTION}

Publishing Coordination

Jéssica Dametta

Editorial Intern

Paula Di Sessa Vavlis

Language Editor

Daniel de Almeida Leão
Layout Designer

Emap

Graphic Designer

Libro 